\title{
PEMANFAATAN FUNGI MIKORIZA ARBUSKULA LOKAL DAN TANAMAN INANG Desmodium spp. UNTUK MENINGKATKAN PERTUMBUHAN BIBIT CENDANA (Santalum album Linn.)
}

\author{
Utilization of Local Arbuscular Nyhorrizhal Fungi (AMF) and Desmodium spp. Host Plants on \\ Promoting Sandalwood (Santalum album Linn.) Seedling Growth
}

\author{
Abdonia W. Finmeta ${ }^{1}$, Irdika Mansur ${ }^{2}$, dan Arum Sekar Wulandari ${ }^{2}$ \\ ${ }^{1}$ Program Studi Biologi, Fakultas MIPA, Universitas PGRI, Kupang, NTT \\ ${ }^{2}$ Departemen Silvikultur, Fakultas Kehutanan, IPB
}

\begin{abstract}
Sandalwood (Santalum album Linn.) is one of important native tree species in East Nusa Tenggara, slow-growing species with high economic value. The aims of this research were to analyze the effectiveness of local AMF inoculum and utilization of host plants to improve the growth of Sandalwood seedlings in the nursery. The research used complitely randomised design (CRD)-split plot design where origin of AMF soil inoculum as the main plot namely control (MO), soil inoculum from Nano Vilage (M1), HTC Bu'at (M2) and Demplot Cendana Sisismeni (M3). While the host plants as the sub-plot, consist of control no host plant (T0), Desmodium ovalifolium (T1), Desmodium heterophyllum (T2) and Alternanthera sp. (T3). The result showed that the local AMF and host plants applications effectively improved Sandalwood seedling growth, especially in heigth, number of leaves and diameter. The best interaction of soil inoculum from HTC Bu'at and D. heterophyllum (M2T2) increased plant height, number of leaves, diameter, shoot dry weight $(B K P)$, root colonization, shoot root ratio (NPA) and seed quality index (IMB) compared with control. Soil inoculum interaction from HTC Bu'at and D. heterophyllum host plants were exellent for improved the quality of Sandalwood seedlings.
\end{abstract}

Key words : Alternanthera, arbuscular mychorrizhal fungi, Desmodium, sandalwood

\section{PENDAHULUAN}

Cendana (Santalum album Linn.) merupakan jenis tanaman asli Nusa Tenggara Timur (NTT), tergolong jenis yang pertumbuhannya lambat tetapi memiliki nilai ekonomi tinggi karena kandungan minyak atsiri pada kayu terasnya serta memiliki aroma khas. Cendana di Indonesia (NTT) merupakan cendana terbaik di dunia yang menghasilkan minyak cendana dengan kadar santalol yang tinggi dibandingkan dengan jenis cendana yang terdapat di negara penghasil cendana lainnya seperti Australia, India, Selandia Baru, dan Fiji (Agusta dan Jamal 2001). Kontribusi cendana bagi perekonomian daerah khususnya Pendapatan Asli Daerah (PAD) Provinsi NTT pada tahun 1990-1997 berkisar $14-37 \%$, dengan rata-rata kontribusi $22.61 \%$ atau sebesar Rp 4071925 588. Pada tahun 2000 terjadi penurunan dimana cendana tidak memberikan kontribusi terhadap PAD (BanoEt 2000). Penyebab turunnya produksi cendana adalah eksploitasi yang berlebihan dan kebijakan pengelolaan cendana melalui berbagai peraturan daerah (Perda) yakni kesalahan pengelolaan yang mengutamakan aspek ekonomi tanpa mempertimbangkan aspek kelestarian atau ekologi dan sosial (Darmokusumo et al. 2001). Peningkatan eksploitasi cendana yang tidak diimbangi dengan upaya konservasi berdampak terhadap bahaya kepunahan.
Akibat adanya deviasi antara tindakan eksploitasi yang tidak diimbangi dengan kegiatan konservasi maka oleh lembaga IUCN (International of Union Conservation of Natural Resource) mengkategorikan cendana sebagai vulnerable (hampir punah) dan oleh CITES dengan kategori Apendix II. Upaya pemulihan potensi dan pelestarian cendana di NTT telah banyak dilakukan, namun keberhasilannya sangat rendah karena kurangnya informasi tentang teknik penanganan benih dan pembudidayaan. Upaya pengembangan sistem silvikultur merupakan solusi penting yang perlu dilakukan untuk mengatasi masalah budidaya cendana di NTT.

Fungi mikoriza arbuskula (FMA) berpotensi besar sebagai pupuk hayati bagi tanaman karena memfasilitasi penyerapan hara dalam tanah sehingga meningkatkan pertumbuhan tanaman, serta efektif dalam perbaikan dan budidaya jenis terancam punah (Sharma et al. 2008). FMA dapat ditemukan hampir pada semua ekosistem, termasuk pada lahan masam (Kartika 2006) dan kondisi lingkungan bersalinitas tinggi (Delvian 2007). Menurut Smith dan Read (2008), FMA dapat berasosiasi dengan hampir $90 \%$ jenis tanaman. Walaupun demikian, tingkat populasi dan komposisi jenis FMA sangat beragam dan dipengaruhi oleh karakteristik tanaman dan faktor lingkungan seperti suhu, pH tanah, kelembaban tanah, kandungan fosfor 
dan nitrogen, serta konsentrasi logam berat (Adewole et al. 2010). Dengan demikian FMA memiliki peran fungsional yang sangat penting bagi tanaman yakni sebagai bioprosesor, bioprotektor, bioaktifator dan bioagregator (Nusantara et al. 2012; Prihastuti 2007). Peranan fungsional dari FMA dapat dimanfaatkan untuk berbagai kepentingan yakni meningkatkan jumlah dan mutu hasil tanaman, mengurangi kebutuhan akan pupuk dan pestisida, mengurangi erosi, mereduksi emisi $\mathrm{CO}_{2}$ dan meningkatkan kesuburan tanah (Sharma 2002).

Cendana merupakan tanaman semiparasit yang hidupnya sangat bergantung kepada keberadaan tanaman lain sebagai inang. Selama hidupnya, cendana membutuhkan tanaman inang mulai dari tingkat persemaian (primary host), dan penanaman di lapangan (secondary host), bahkan secara alami cendana yang tumbuh di alam dapat berasosiasi dengan pohon-pohon yang ada disekitarnya sehingga bentuk asosiasi yang berlangsung sepanjang hidupnya (tertiary host). Tanaman penutup tanah atau legume cover crop (LCC) adalah tanaman yang sangat potensial untuk melindungi tanah dari ancaman kerusakan oleh erosi karena sifatnya menjalar, tidak melilit tanaman pokok (Desmodium ovalifolium dan Desmodium heterophyllum), daunnya selalu hijau dan menghasilkan banyak bahan organik, serta memiliki kemampuan hidup pada lahan terbuka dengan kondisi tanah yang kritis dan marginal (Schmidt et al. 1997).

Desmodium spp. dapat tumbuh dengan baik pada lahan pasca tambang bahkan menghasilkan biomassa yang lebih besar dibandingkan pada tanah subsoil (Hasanah et al. 2014). Kemampuan Desmodium spp. dalam menghasilkan biomassa organik yang tinggi berperan dalam memperbaiki kondisi tanah secara fisik dan kimia sehingga dapat meningkatkan pertumbuhan tanaman. Mulsa organik yang dihasilkan dari Desmodium spp. berfungsi meningkatkan kadar air tanah, menurunkan suhu harian tanah, mengurangi penguapan tanah dan mampu menurunkan kepadatan tanah. Dengan demikian pemanfaatan FMA lokal dan tanaman inang Desmodium spp. diharapkan menjadi solusi untuk mempercepat pertumbuhan cendana di persemaian dan pada penanaman di lapangan. Penelitian ini bertujuan untuk menganalisis efektivitas FMA lokal dan pemanfaatan tanaman inang Desmodium spp. untuk meningkatkan pertumbuhan bibit cendana.

\section{METODE PENELITIAN}

\section{Tempat dan Waktu}

Penelitian ini dilakukan pada bulan Januari-Mei 2017. FMA lokal berasal dari 3 lokasi rizosfer tegakan cendana di NTT yakni Kabupaten Kupang (Demplot Cendana Sisimeni), Kabupaten Timor Tengah Selatan (Hutan Tanaman Cendana/HTC Bu'at) dan tegakan alami cendana di Desa Nano Kecamatan Amanatun Selatan. Identifikasi FMA di Laboratorium Silvikultur, penangkaran (trapping) FMA dan pembibitan cendana dilakukan di rumah kaca Silvikultur (green house G) SEAMEO BIOTROP

\section{Alat dan Bahan}

Alat yang digunakan dalam penelitian ini yaitu alat tulis, penggaris, kamera, kaliper, oven, autoclave, disecting microscope, compound microscope, gelas objek, timbangan analitik dan polybag. Bahan yang digunakan adalah benih cendana, benih Desmodium spp., topsoil, inokulum FMA lokal hasil panangkaran (trapping) yang dilakukan pada penelitian sebelumnya, amplop kertas.

\section{Prosedur Penelitian}

\section{Persiapan bibit cendana dan tanaman inang}

Persiapan bibit cendana diawali dengan persiapan semai benih yang diperoleh dari pohon induk cendana di Kabupaten Timor Tengah Selatan (TTS) propinsi NTT. Proses pematahan dormasi benih dengan cara benih cendana direndam dengan air (suhu $50^{\circ} \mathrm{C}$ ) selama 12 jam, kemudian dikeringanginkan selama 6 jam (proses ini dilakukan secara berulang selama 3 hari). Sebelum benih ditabur pada bak kecambah, benih cendana direndam dengan larutan fungisida dan bakterisida dengan konsentrasi masing-masing $0.2 \mathrm{~g} / 100 \mathrm{~mL}$ aquades selama 60 menit. Media kecambah yang digunakan adalah campuran topsoil, pasir, dan arang sekam dengan perbandingan 2:1:1 yang sebelumnya telah disterilkan dengan menggunakan autoklaf. Tanaman inang yang digunakan adalah Desmodium ovalifolium, Desmodium heterophyllum dan Alternanthera sp. (krokot) sebagai pembanding. Perbanyakan $D$. ovalifolium dilakukan dengan metode generatif yaitu dengan benih. Benih diperoleh dari pemanenan polong buah yang sudah masak dari kebun percobaan SEAMEO BIOTROP. Perbanyakan $D$. heterophyllum dan Alternanthera sp. dilakukan secara vegetatif yaitu dengan stek batang. Ukuran batang stek yang digunakan sepanjang $3 \mathrm{~cm}\left(2 \frac{1}{2}\right.$ buku $)$ yang dipotong secara diagonal.

\section{Persiapan media sapih}

Media yang digunakan untuk menyapih bibit cendana adalah tanah topsoil dari kebun penelitian SEAMEO BIOTROP. Sebelum dimasukkan ke dalam polybag, media tanah diayak terlebih dahulu kemudian disterilkan menggunakan autoklaf selama 1 jam. Sehari sesudah sterilisasi, tanah dimasukkan ke dalam polybag berukuran 15 × $20 \mathrm{~cm}$, kemudian dihamparkan atau ditebarkan inokulum FMA lokal dari masing-masing lokasi sesuai dengan perlakuan yakni FMA lokal asal Desa Nano (M1), FMA lokal asal HTC Bu'at (M2) dan FMA lokal asal Demplot Cendana Sisimeni (M3).

\section{Inokulasi dan Pemeliharaan}

Inokulum FMA lokal dihamparkan atau ditebar sebanyak $5 \mathrm{~g}$ per polibag atau \pm 50 spora. Inokulum FMA lokal yang digunakan berisi spora dominan yang ditemukan saat penangkaran pada penelitian sebelumnya (Tabel 1). Tanaman inang yang sudah tumbuh, disapih dan langsung ditanam pada masingmasing polybag sesuai perlakuan. Seminggu sesudah penyapihan tanaman inang, bibit cendana yang berumur 1 bulan atau setelah terdapat $2-4$ helai daun siap 
Tabel 1 Deskripsi fungi mikoriza arbuskula (FMA) dominan yang diisolasi dari tegakan cendana di NTT

\begin{tabular}{|c|c|c|c|}
\hline Tipe spora FMA & Karakteristik Morfologi & Asal tegakan cendana & Jumlah Spora per $10 \mathrm{gr}$ \\
\hline Glomus sp. 8 & $\begin{array}{l}\text { Spora berbentuk bulat, berwarna } \\
\text { orange, memiliki ukuran yang } \\
\text { kecil, dinding spora yang tebal } \\
\text { dengan dinding bagian luar yang } \\
\text { berwarna gelap, tidak bereaksi } \\
\text { dengan larutan Melzer. Ukuran } \\
142-243.56 \times 127-241.3\end{array}$ & Nano, Bu'at, Sisimeni & $102(42,19,41)$ \\
\hline Acaulospora sp.5 & $\begin{array}{l}\text { Spora berbentuk bulat, sebelumnya } \\
\text { berwarna putih bening, berubah } \\
\text { menjadi hyaline saat bereaksi } \\
\text { dengan larutan Melzer, permukaan } \\
\text { kasar, dan nampak seperti kulit } \\
\text { jeruk, dinding spora tipis, ada } \\
\text { cicatrix. Ukuran 121.5-142 x } \\
140.26\end{array}$ & Nano dan Bu'at & $78(40,38)$ \\
\hline
\end{tabular}

disapih dan ditanam berdampingan dengan tanaman inang. Pemeliharaan meliputi penyiraman yang dilakukan satu kali dalam sehari (pagi hari) dan penyiangan atau pembersihan terhadap gulma yang tumbuh.

\section{Variabel Pengamatan}

Tinggi bibit (cm), jumlah daun, diameter bibit (mm), berat kering pucuk (BKP), berat kering akar (BKA), kolonisasi FMA (\%), nisbah pucuk akar (NPA) dan indeks mutu bibit (IMB) diukur diakhir penelitian. Pengukuran BKP dan BKA dilakukan setelah bibit dipanen (14 MST), masing-masing bagian dipisahkan dan di oven selama 48 jam pada suhu $80{ }^{\circ} \mathrm{C}$. Kolonisasi FMA (\%) dilakukan dengan metode pewarnaan akar (Philips dan Hayman 1970), persentase kolonisasi akar dihitung dengan rumus yang dikembangkan oleh Brundrett et al. (1996), sedangkan nilai kolonisasi menurut O'Connur et al. (2001). Pengukuran NPA merupakan perbandingan antara biomassa pucuk (BKP) dan biomassa akar (BKA). Bibit yang baik dan mampu bertahan di lapangan yaitu jika memiliki IMB (QI) $>0.09$. Indeks Mutu Bibit dapat dihitung dengan menggunakan rumus Dickson et al. (1960):

$$
=\frac{\mathrm{BKP}(\mathrm{g})+\mathrm{BKA}(\mathrm{g})}{\operatorname{tinggi}(\mathrm{cm}) / \operatorname{diameter}(\mathrm{mm})+\mathrm{BKP}(\mathrm{g}) / \mathrm{BKA}(\mathrm{g})}
$$

\section{Analisis Data}

Rancangan percobaan yang digunakan dalam penelitian ini adalah Rancangan Acak Lengkap (RAL) dengan petak terbagi (split plot design). Faktor pemberian mikoriza/inokulasi FMA sebagai petak utama terdiri dari empat taraf yaitu tanpa FMA/ kontrol (M0), FMA lokal asal Desa Nano (M1), FMA lokal asal HTC Bu'at (M2) dan FMA lokal asal Demplot Cendana Sisimeni (M3) dan penanaman bersama tanaman inang (anak petak) yang terdiri dari empat taraf yaitu kontrol (T0), D. ovalifolium (T1), D. heterophyllum (T2) dan Alternanthera sp. (T3). Dari 2 faktor tersebut terdapat 16 kombinasi perlakuan, tiap perlakuan terdiri dari 5 ulangan dan setiap ulangan terdiri atas 4 unit sehingga terdapat 320 bibit yang diamati. Data hasil dianalisis menggunakan sidik ragam program SAS 9.1. Jika perlakuan berpengaruh nyata dilakukan uji lanjut Duncan Multiple Range Test (Mattjik dan Sumertajaya 2013).

\section{HASIL DAN PEMBAHASAN}

\section{Pertumbuhan tanaman}

Pertumbuhan tanaman diindikasikan dengan adanya pertambahan jumlah dan dimensi tanaman baik tinggi, jumlah daun maupun diameter. Interaksi FMA lokal dan tanaman inang terhadap pertumbuhan bibit cendana seperti yang ditunjukkan pada Tabel 2. Hasil analisis ragam memperlihatkan pengaruh tersebut sangat nyata pada semua peubah yang diamati.

Tabel 2 Rekapitulasi hasil analisis ragam semai

\begin{tabular}{|c|c|c|c|}
\hline \multirow[b]{2}{*}{ Peubah } & \multicolumn{3}{|c|}{ Perlakuan } \\
\hline & FMA & $\begin{array}{c}\text { Tanaman } \\
\text { inang }\end{array}$ & $\begin{array}{c}\text { FMA x } \\
\text { Tanaman } \\
\text { inang }\end{array}$ \\
\hline
\end{tabular}
cendana terhadap peubah yang diamati

\begin{tabular}{|c|c|c|c|}
\hline $\begin{array}{l}\text { Pertambahan tinggi } \\
\text { (cm) } 14 \text { MST }\end{array}$ & $*$ & $* *$ & $* *$ \\
\hline $\begin{array}{l}\text { Pertambahan daun } \\
\text { (helai) } 14 \mathrm{MST}\end{array}$ & ** & $* *$ & $* *$ \\
\hline $\begin{array}{l}\text { Pertambahan diameter } \\
(\mathrm{mm}) 14 \mathrm{MST}\end{array}$ & $*$ & $* *$ & $* *$ \\
\hline Berat Kering Pucuk (g) & tn & $* *$ & $* *$ \\
\hline Berat Kering Akar (g) & tn & $* *$ & $* *$ \\
\hline Kolonisasi FMA (\%) & $* *$ & $* *$ & $* *$ \\
\hline
\end{tabular}

Efektivitas setiap jenis FMA yang ditambahkan dengan tanaman inang memiliki pertambahan dimensi yang berbeda-beda (Tabel 3). Hasil uji lanjut Duncan pada 14 MST memperlihatkan bahwa interaksi tertinggi adalah perlakuan FMA lokal asal HTC Bu'at dan tanaman inang D. heterophyllum (M2T2) sangat efektif terhadap pertumbuhan tanaman seperti pertambahan tinggi, jumlah daun dan diameter bibit cendana. FMA lokal asal HTC Bu'at dan tanaman inang $D$. heterophyllum (M2T2) merupakan interaksi terbaik yang dapat meningkatkan persentase pertambahan tinggi bibit cendana mencapai $163.47 \%(17.02 \mathrm{~cm})$, 
pertambahan jumlah daun $54.68 \%$ (16.56 helai), dan pertambahan diameter batang sebesar $74.42 \%$ (1.50 $\mathrm{mm}$ ) jika dibandingkan kontrol (M0T0). Meningkatnya pertambahan tinggi pada perlakuan tunggal tanaman inang Alternanthera sp. (M0T3) disebabkan karena secara alami tanaman inang Alternanthera sp. memiliki hara esensial seperti kalsium $(\mathrm{Ca})$ dan magnesium $(\mathrm{Mg})$. Kalsium (Ca) berperan penting dalam pertumbuhan vegetatif bagi tanaman dan memiliki respon dalam merangsang pertumbuhan bulu-bulu akar sehingga meningkatkan daya serap terhadap air unsur hara lain dalam tanah. Pertumbuhan bibit cendana dengan nilai terendah terlihat pada perlakuan kontrol (M0T0) dan perlakuan tunggal inokulasi FMA lokal (M1, M2 dan M3) untuk semua peubah yang diamati, hal ini diakibatkan cendana yang besifat semiparasit. Tanaman inang Desmodium spp. sangat potensial dalam meningkatkan pertumbuhan bibit cendana, Cajanus cajan (inang primer) meningkatkan pertambahan tinggi bibit cendana menjadi $90 \mathrm{~cm}$ dan Erythroxylum monogynum (inang sekunder) dapat meningkatkan pertambahan tinggi bibit cendana menjadi $116 \mathrm{~cm}$ setelah 5 bulan penanaman (Durairaj dan Kamaraj 2016).

Asosiasi FMA lokal dan tanaman inang memiliki efektivitas yang tinggi terhadap pertumbuhan tanaman. Tanaman inang Desmodium spp. memiliki kemampuan yang tinggi untuk bersimbiosis dengan rhizobium dan membentuk bintil akar pada sistem perakaran (Mansur 2013), legum memiliki transportasi inhibitor yang berfungsi memberikan signal terhadap perkembangan bintil akar (Benkova et al. 2003). Mulsa organik yang dihasilkan dari tanaman inang Desmodium spp. terdekomposisi dalam media tanam sehingga dapat bermanfaat bagi pertumbuhan tanaman. Satria (2011) menyatakan bahwa pertambahan jumlah daun nilam (Pogostemon cablin. Benth.) sejalan dengan pertambahan tinggi tanaman sehingga semakin tinggi tanaman maka jumlah daunnya juga semakin banyak. Tuheteru dan Husna (2011) melaporkan bahwa jumlah daun Albizia saponaria dapat dipengaruhi oleh ketersediaan unsur $\mathrm{N}$ dan $\mathrm{P}$ dalam media karena defisiensi unsur $\mathrm{N}$ akan terlihat pertama kali pada penurunan ukuran daun, sedangkan defisiensi fosfor sangat berpengaruh terhadap jumlah daun. Pertambahan diameter batang dipengaruhi oleh proses fotosintesis dan $\mathrm{H}_{2} \mathrm{O}$. Kemampuan tanaman inang terhadap fiksasi nitrogen melalui rhizobium yang terbentuk pada akar tanaman inang akan meningkatkan unsur hara $\mathrm{N}$ dan $\mathrm{P}$ lebih banyak tersedia, proses ini dapat meningkatkan aktivitas jaringan meristem pada ujung batang dan kambium sehingga tumbuhan dapat bertambah tinggi dan besar.

\section{Berat kering pucuk dan akar tanaman (g)}

Hasil uji Duncan biomassa tanaman diperlihatkan pada Tabel 4. Interaksi antara inokulasi FMA lokal dan tanaman inang menunjukkan pengaruh yang sangat nyata terhadap berat kering pucuk (BKP) dan berat kering akar (BKA). Bobot tertinggi BKP pada perlakuan tanaman inang Alternanthera sp. tanpa inokulasi FMA (M0T3), FMA lokal asal Desa Nano dan Alternanthera sp. (M1T3), FMA lokal asal HTC Bu'at dengan inang D. heterophyllum (M2T2) dan inang Alternanthera sp. (M2T3), yang tidak berbeda nyata dengan perlakuan FMA lokal asal Sisimeni dengan inang Alternanthera sp. (M3T3). Demikian pula bobot tertinggi untuk BKA pada perlakuan FMA lokal asal HTC Bu'at dengan tanaman inang Alternanthera sp. (M2T3) yang tidak berbeda nyata dengan perlakuan FMA lokal asal HTC Bu'at dengan inang $D$. heterophyllum. (M2T2). Persentase peningkatan BKP secara berturut-turut 344.44\% (M0T3, M1T3), 338.88\% (M2T2) dan $333.33 \%$ (M2T3).Persentase berat kering akar tertinggi adalah $625 \%$ (M2T3).

Tabel 3 Pengaruh interaksi FMA lokal dan tanaman inang terhadap pertambahan tinggi, pertambahan daun, diameter semai cendana umur 14 minggu setelah tanam.

Tanaman inang

$\begin{array}{ccccc}\text { Kontrol } & \text { D. ovalifolium } & \text { D.heterophyllum (T2) } & \text { Alternanthera } & \text { sp. } \\ (\mathrm{T} 3) & (\mathrm{T} 1) & \text {. }\end{array}$

\begin{tabular}{|c|c|c|c|c|}
\hline \multicolumn{5}{|c|}{ Pertambahan tinggi $(\mathrm{cm})$} \\
\hline M0 (tanpa FMA) & $6.5 \mathrm{~d}$ & $10.9 \mathrm{bc}$ & $11.1 \mathrm{bc}$ & $16.7 \mathrm{a}$ \\
\hline M1 (FMA lokal asal Desa Nano) & $6.9 \mathrm{~d}$ & $10.0 \mathrm{~cd}$ & $13.6 \mathrm{ab}$ & $14.0 \mathrm{ab}$ \\
\hline M2 (FMA lokal asal HTC Bu'at) & $7.2 \mathrm{~d}$ & $15.1 \mathrm{a}$ & $17.0 \mathrm{a}$ & $14.1 \mathrm{ab}$ \\
\hline M3 (FMA lokal asal Sisismeni) & $7.3 \mathrm{~d}$ & $9.2 \mathrm{~cd}$ & $14.3 \mathrm{ab}$ & $13.5 \mathrm{ab}$ \\
\hline \multicolumn{5}{|c|}{ Pertambahan daun (helai) } \\
\hline M0 (tanpa FMA) & $10.90 \mathrm{e}$ & $11.18 \mathrm{de}$ & $12.10 \mathrm{cde}$ & $15.64 a b$ \\
\hline M1 (FMA lokal asal Desa Nano) & $11.18 \mathrm{de}$ & 12.44 cde & $13.34 \mathrm{c}$ & $14.92 \mathrm{~b}$ \\
\hline M2 (FMA lokal asal HTC Bu'at) & 12.48 cde & $16.56 \mathrm{a}$ & $16.86 \mathrm{a}$ & $16.90 \mathrm{a}$ \\
\hline M3 (FMA lokal asal Sisismeni) & $12.80 \mathrm{c}$ & $13.46 \mathrm{c}$ & $15.88 \mathrm{ab}$ & $14.89 \mathrm{~b}$ \\
\hline \multicolumn{5}{|c|}{ Pertambahan diameter (mm) } \\
\hline M0 (tanpa FMA) & $0.86 \mathrm{f}$ & 1.12 cdef & $1.32 \mathrm{abcd}$ & $1.26 \mathrm{abcde}$ \\
\hline M1 (FMA lokal asal Desa Nano) & 1.12 cdef & 1.22 abcde & 1.18 bcde & $1.24 \mathrm{abcde}$ \\
\hline M2 (FMA lokal asal HTC Bu'at) & $1.04 \mathrm{def}$ & $1.48 \mathrm{ab}$ & $1.50 \mathrm{a}$ & $1.38 \mathrm{abc}$ \\
\hline M3 (FMA lokal asal Sisismeni) & 0.96 ef & $0.96 \mathrm{ef}$ & $1.48 \mathrm{ab}$ & 1.14 cdef \\
\hline
\end{tabular}


Tabel 4 Pengaruh interaksi FMA dan tanaman inang terhadap BKP dan BKA semai cendana umur 14 minggu setelah tanam.

Tanaman inang
Asal FMA lokal
Kontrol
D. ovalifolium
D. heterophyllum (T2)
Alternanthera $\mathrm{sp.}$
(T0)
(T1)
(T3)

\begin{tabular}{|c|c|c|c|c|}
\hline \multicolumn{5}{|c|}{ Berat Kering Pucuk (g) } \\
\hline M0 (tanpa FMA) & $0.36 \mathrm{~d}$ & $1.18 \mathrm{bc}$ & $0.92 \mathrm{c}$ & $1.60 \mathrm{a}$ \\
\hline M1 (FMA lokal asal Desa Nano) & $0.32 \mathrm{~d}$ & $1.12 \mathrm{bc}$ & $1.18 \mathrm{bc}$ & $1.60 \mathrm{a}$ \\
\hline M2 (FMA lokal asal HTC Bu'at) & $0.30 \mathrm{~d}$ & $1.30 \mathrm{abc}$ & $1.58 \mathrm{a}$ & $1.56 \mathrm{a}$ \\
\hline M3 (FMA lokal asal Sisismeni) & $\begin{array}{l}0.38 \mathrm{~d} \\
\text { Berat Ke }\end{array}$ & $1.02 \mathrm{bc}$ & $1.10 \mathrm{bc}$ & $1.36 \mathrm{ab}$ \\
\hline M0 (tanpa FMA) & $0.08 \mathrm{~h}$ & 0.32 def & $0.22 \mathrm{fg}$ & 0.36 bcde \\
\hline M1 (FMA lokal asal Desa Nano) & $0.10 \mathrm{gh}$ & $0.32 \mathrm{def}$ & 0.34 cdef & $0.44 \mathrm{bcd}$ \\
\hline M2 (FMA lokal asal HTC Bu'at) & $0.08 \mathrm{~h}$ & $0.46 a b c$ & $0.48 \mathrm{ab}$ & $0.58 \mathrm{a}$ \\
\hline M3 (FMA lokal asal Sisismeni) & $0.10 \mathrm{gh}$ & 0.26 ef & $0.32 \mathrm{def}$ & $0.40 \mathrm{bcd}$ \\
\hline
\end{tabular}

*Angka yang diikuti huruf yang sama pada kolom sama menunjukkan tidak berbeda nyata berdasarkan Uji Duncan pada taraf $\alpha$ $5 \%$.

Tabel 5 Persentase kolonisasi FMA pada bibit cendana umur 14 minggu setelah tanam Tanaman inang

Asal FMA lokal

Kontrol D.ovalivolium

(T0)

D.heterophyllum (T2)

Alternanthera $\mathrm{sp}$.

(T3)

\begin{tabular}{lllll}
\hline & \multicolumn{3}{l}{ Kolonisasi Akar oleh FMA (\%) } & \\
M0 (tanpa FMA) & $30.0 \mathrm{fg}$ & $36.0 \mathrm{efg}$ & $36.0 \mathrm{efg}$ & $36.0 \mathrm{efg}$ \\
M1 (FMA lokal asal Desa Nano) & $47.5 \mathrm{cdef}$ & $60.0 \mathrm{abcd}$ & $51.7 \mathrm{abc}$ & $42.0 \mathrm{def}$ \\
M2 (FMA lokal asal HTC Bu'at) & $47.5 \mathrm{cdef}$ & $62.0 \mathrm{abc}$ & $70.0 \mathrm{a}$ & $68.0 \mathrm{ab}$ \\
M3 (FMA lokal asal Sisimeni) & $25.0 \mathrm{~g}$ & $50.0 \mathrm{bcde}$ & $58.3 \mathrm{abcd}$ & $58.0 \mathrm{abcd}$ \\
\hline
\end{tabular}

*Angka yang diikuti huruf yang sama pada kolom sama menunjukkan tidak berbeda nyata berdasarkan Uji Duncan pada taraf $\alpha$ $5 \%$.

Rendahnya nilai biomassa pucuk dan akar pada perlakuan kontrol dan perlakuan tunggal dari semua jenis FMA lokal diakibatkan karena struktur perakaran cendana yang sedikit, lambat pertumbuhannya serta kemungkinan bibit cendana dalam kondisi stres sehingga membutuhkan waktu untuk beradaptasi dengan FMA lokal yang terdapat pada media tanam. Berbeda dengan tanaman inang Alternanthera sp. yang memberikan respon terbaik terhadap BKP pada semua perlakuan karena unsur hara kalsium $(\mathrm{Ca})$ yang secara alami terdapat pada tanaman Alternanthera sp. yang berfungsi sebagai hara esensial yang lebih banyak dibutuhkan oleh tanaman. Peran FMA dalam menyerap unsur hara terutama fosfat, air dan karbohidrat berpengaruh terhadap biomassa tanaman dan merupakan indikator utama yang umum digunakan untuk mengetahui baik atau tidaknya pertumbuhan bibit. Semakin tinggi tanaman menyerap unsur hara, maka semakin meningkat pula biomassa tanaman karena aktivitas fotosintesis yang berlangsung lebih efisien (Karespesina 2007).

\section{Kolonisasi FMA}

Persentase kolonisasi FMA (Tabel 5) pada bibit cendana tergolong tinggi berdasarkan kategori oleh O'Connur et al. (2001) yakni lebih dari 30\%. Persentase kolonisasi tertinggi pada perlakuan FMA lokal asal HTC Bu'at dan tanaman inang D. heterophyllum (M2T2) dengan nilai 70\% dan membentuk struktur yang lengkap pada jaringan akar mulai dari hifa, vesikula, dan arbuskula.

Tingginya persen kolonisasi pada perlakuan kontrol kemungkinan terjadi kontaminasi dengan tanaman yang diberi perlakuan FMA karena kondisi lingkungan yang tidak terkontrol, serta proses penyiraman yang salah. Efektivitas FMA untuk mengkolonisasi akar tanaman memberikan respon yang berbeda-beda baik jenis FMA maupun jenis tanaman yang akan digunakan. FMA membutuhkan waktu yang cukup lama untuk mengkolonisasi akar tanaman, bibit cendana memiliki respon yang berbeda terhadap jenis FMA, inokulasi bibit cendana dengan Glomus mosseae dan pada naungan $50 \%$ dapat memperlihatkan bentuk kolonisasi yang maksimum sebesar $68 \%$ pada umur 8 bulan setelah tanam (Binu et al. 2015). Selain itu, ada kemungkinan setiap FMA mempunyai preferensi yang berbeda terhadap eksudat yang dihasilkan bibit sehingga efektivitas dari masing-masing FMA juga berbeda seperti pada tanaman pisang yang dilaporkan oleh Rainiyati et al. (2009) setelah diinokulasi 5 jenis FMA Glomus dan Mycofer menunjukkan reaksi yang berbeda-beda. 
Tabel 6 Pengaruh interaksi FMA dan tanaman inang terhadap rasio pucuk akar (NPA) dan indeks mutu bibit (IMB) Cendana umur 14 minggu setelah tanam

Tanaman inang

Asal FMA lokal

Kontrol (T0)
D. ovalifolium

(T1)
D. heterophyllum (T2)

Alternanthera sp. (T3)

M0 (tanpa FMA)
M1 (FMA lokal asal Desa Nano)
M2 (FMA lokal asal HTC Bu'at)
M3 (FMA lokal asal Sisismeni)
M0 (tanpa FMA)
M1 (FMA lokal asal Desa Nano)
M2 (FMA lokal asal HTC Bu'at)
M3 (FMA lokal asal Sisismeni)

\section{Biomassa dan Kualitas Tanaman}

Nisbah pucuk akar (NPA) merupakan faktor penting dalam pertumbuhan tanaman yang mencerminkan perbandingan antara proses transpirasi dan luasan fotosintesis dari tanaman dengan kemampuan penyerapan air dan mineral (Setyaningsih et al. 2000). Hasil uji Duncan (Tabel 6) menunjukkan kualitas bibit cendana dengan nilai NPA berkisar dari $2.46-4.74$ dan nilai ini menunjukkan bibit cendana siap tanam di lapangan pada umur 3.5 bulan. Bibit yang mampu hidup dan bertumbuh dengan baik umumnya memiliki nilai NPA berkisar 2-5 (Alrasyid 1972).

Nilai IMB cendana berdasarkan hasil penelitian Surata (2012) adalah 0.28 yang mendekati standar mutu bibit cendana yaitu 0.3 . Kualitas bibit cendana yang baik dan telah siap ditanam harus memiliki tinggi lebih dari $20 \mathrm{~cm}$, diameter lebih dari $3 \mathrm{~mm}$ dan nilai indeks mutu bibit adalah 0.3 (Annapurna et al. 2004). Nilai IMB cendana yang ditunjukkan pada Tabel 6 pada penelitian ini berkisar dari $0.09-0.14$ dan hasil ini sesuai dengan standar mutu bibit menurut Dickson et al. (1960) yakni lebih dari 0.09 bagi semua perlakuan kecuali kontrol (M0T0) dan perlakuan tunggal FMA lokal asal Desa Nano, FMA lokal asal HTC Bu'at dan FMA lokal asal Demplot Cendana Sisimeni.

\section{SIMPULAN DAN SARAN}

Efektivitas Fungi Mikoriza Arbuskula (FMA) lokal dan interaksinya dengan tanaman inang Desmodium spp. dapat meningkatkan pertumbuhan bibit cendana. Secara umum perlakuan inokulasi FMA lokal asal HTC Bu'at dengan tanaman inang Desmodium heterophyllum meningkatkan pertambahan tinggi, jumlah daun, pertambahan diameter, berat kering pucuk, kolonisasi FMA, nisbah pucuk akar dan indeks mutu bibit. Interaksi ini sangat efektif untuk meningkatkan pertumbuhan bibit cendana pada awal penanaman di lapangan.

Disarankan agar produksi bibit cendana bermikoriza harus selalu dengan tanaman inang. FMA yang akan digunakan harus dibedakan antara tipe genus dan spesiesnya sehingga dapat diketahui jenis FMA yang spesifik dengan tanaman cendana.

\section{UCAPAN TERIMA KASIH}

Terima kasih yang sebesar-besarnya disampaikan kepada yang terhormat Direktur SEAMEO BIOTROP Bogor yang telah memberikan izin kepada penulis untuk melakukan penelitian. Ucapan terima kasih disampaikan juga kepada Dr Dewi Wulandari, M.Agr selaku koordinator Laboratorium Silvikultur SEAMEO BIOTROP yang telah memberikan kesempatan bagi penulis untuk menggunakan semua peralatan dan bahan yang dibutuhkan selama penelitian berlangsung. Ucapan Terima kasih juga penulis sampaikan kepada Bapak Sunardi Ikai selaku Teknisi Laboratorium dan Green House yang telah banyak membantu penulis selama melakukan penelitian.

\section{DAFTAR PUSTAKA}

Adewole MB, Awotoye OO, Ohiembor MO, Salami AO. 2010. Influence of micorrhizal fungi on phytoremidiating potential and yield of sunflower in $\mathrm{Cd}$ and $\mathrm{Pb}$ poluted soils. J Agric Sci 55(1): 17-28.

Agusta A, Jamal Y. 2001. Fitokimia dan farmakologi cendana (Santalum album Linn.) Laboratorium Fitokimi Balitbang Botani Puslitbang Biologi-LIPI Bogor (IN): Edisi Khusus Masalah Cendana NTT Berita Biologi 5(5).

Alrasyid H. 1972. Teknik persemaian dan penanaman di Jepang. Report Training Course Forestry in Japan. Lembaga Penelitian Hutan Bogor. 15 halaman.

Annapurna D. Rathore TS, Joshi G. 2004. Effect of Container and Size on TheGrowth and Quality of Seedlings of Indian Sandalwood (Santalum album L).Journal of Sustainable Forestry 67(2): 82-87. Canberra (AU): Australian Forestry.

BanoEt, 2000. Peranan Cendana dalam Perekonomian NTT: Dulu dan Kini. Prosiding Cendana (Santalum album Linn.) Sumber Daya Otonomi Daerah Nusa Tenggara Timur. Berita Biologi Edisi Khusus. Pusat Penelitian Biologi. LIPI. Hal. 469-474.

Benkova E, Michniewicz M, Sauer M, Teichmann T, Seifertova D, Jurgens G, Friml J. 2003. Local, efflux-dependentauxin gradients as a common nodule for plant organ formation.Cell 115, 591-602. 
Binu NK, Ashokan PK, Balasundaran M. 2015. Influence of different arbuscular mycorrhiza fungi and shade on growth of sandal (Santalum album) seedlings. Kerala Agricultural University. Kerala, India (IN)Journal of Tropical Forest Science 27(2): $158-165$

Brundrett MC, Bougherr N, Dells B, Grove T, Malajezuk N. 1996. Working with mycorrhizas in Forestry and Agriculture. Canberra (AU): Australian Center for International Agriculture Research.

Darmokusumo S, Nugroho AA, Botu EU, Jehamat A, Benggu M. 2001. Upaya memperluas kawasan ekonomi cendana di NTT. Prosiding Cendana (Santalum album Linn.) Sumber Daya Otonomi Daerah Nusa Tenggara Timur. Berita Biologi Edisi Khusus. Pusat Penelitian Biologi. LIPI. Hal. 509. 515.

Delvian 2007. Penggunaan asam humik dalam kultur trapping cendawan mikoriza arbuskula dari ekosistem dengan salinitas tinggi. Jurnal Ilmu Pertanian Indonesia. 9(2): 124-129.

Dickson A, Leaf AL, Hosner JF. 1960. Quality appraisal of white spruce and white pine seedling stock in nurseries. Forest Chron. 36: 10-13.

Durairaj P, Kamaraj M. 2016. Host Species Dependent Vegetatif Growth Parameters of Santalum album Linn.International Journal of Biosciences and Nanosciences 3(6): 90-93. Tamilnadu (IN): PG \& Research Department of Botany Jamal Mohamed College Tiruchirapalli.

Hasanah NI, Wasis B, Mansur I. 2014. Pengembangan Desmodium spp. sebagai tanaman penutup tanah dalam reklamasi lahan pasca tambang. JST 05(1): 7-12.

Karepesina S. (2007). Keanekaragaman Fungi Mikoriza Arbuskula dari Bawah Tegakan Jati Ambon (Tectona grandis Linn.f.) dan Potensi Pemanfaatannya [Tesis]. Bogor (ID): Institut Pertanian Bogor.

Kartika E. 2006. Tanggap Pertumbuhan, Serapan Hara, dan Karakter Morfofisiologi terhadap Cekaman Kekeringan pada Bibit Kelapa Sawit yang Bersimbiosis dengan CMA [Disertasi]. Bogor (ID): Institut Pertanian Bogor.

Mansur I. 2013.Teknik Silvikultur untuk Reklamasi Lahan Bekas Tambang. Bogor (ID): SEAMEO BIOTROP.

Mattjik AA, Sumertajaya AM. 2013. Perancangan Percobaan dengan Aplikasi SAS dan Minitab. Bogor (ID). IPB Press.
Nusantara AD, Bertham YA, Mansur I. 2012. Bekerja dengan Fungi Mikorisa Arbuskula. Bogor (ID): SEAMEO BIOTROP.

O'Connur PJ, Smith SE, Smith FA. 2001. Arbuscular mycorrhizal fungi associations in the southern. Southern Simpson desert. Aust J Bot. 49: 493-499.

Philips JM, Hayman DS. 1970. Improved procedures for clearing roots and staining parasitic and vesiculararbuscular mycorrhizal fungi for rapid assesment of infection. Transct Brit Mycol Soc. 55: 158-161.

Prihastuti. 2007. Isolasi dan karakterisasi mikoriza vesikular-arbuskular di lahan kering masam, Lampung Tengah. Berk. Penel. Hayati: 12(99-106).

Rainiyati, Chozin, Sudarsono, Mansur I. 2009. Pengujian efektivitas beberapa isolat cendawan mikoriza arbuskula (CMA) terhadap bibit pisang (Musa AA RAJA NANGKA) asal kultur jaringan. Berks. Panel Hayati. 15: 63-69.

Satria N. 2011. Induksi akar stek pucuk nilam (Pogostemon cablin. Benth.) dengan beberapa perangsang akar dan pertumbuhannya setelah diinokulasi dengan fungi mikoriza arbuskula [skripsi]. Padang (ID): Universitas Andalas.

Schmidt A, Lascano C E, Maass B L, Kraft R S. 1997. An approach to define $\mathrm{G} \times \mathrm{E}$ interaction in a core collection of Desmodium ovalifolium. ID. 192: 1/59 $-1 / 60$.

Sharma D. 2002. Organic Farming. Cental Acid Zone Research Institute Jodhpur. Agrobios India.

Sharma D, Rupan K, Bhatnagar AK. 2008. Arbuscular mycorrhizal (AM) technology for the concervation of Curculigo orchioides Gaertn: an endangered medicinal herb. World J Microbial Biotechnol. 24: 395-400.

Setyaningsih LY, Munawar, Turjaman M. 2000. Efektivitas Cendawan Mikoriza Arbuskula dan Pupuk NPK terhadap pertumbuhan Bitti. Prosiding Seminar Nasional Mikoriza I. hlm 192-201.

Smith SE, Read DJ. 2008. Mycorrhizal Symbiosis. London (GB). Academic Press.

Surata IK. 2012. Pertumbuhan semai cendana (Santalum album L.) pada beberapa ukuran kantung plastik di daerah semi arid. J Penelitian Kehutanan Wallacea 1(1): 13-25.

Tuheteru FD, Husna. 2011. Pertumbuhan dan Biomassa Albizia saponaria yang diinokulasi Fungi Mikoriza Arbuskula Lokal Sulawesi Tenggara. JST 2(03): 143-148. 